$\begin{array}{ll}\text { Tittle } & \begin{array}{l}\text { LEGAL POLITICS OF WATER RESOURCES } \\ \text { MANAGEMENT IN INDONESIA: ENVIRONMENTAL }\end{array} \\ \text { PIMBAR HUKUM } & \end{array}$

$\begin{array}{ll}\text { DOI } & : \text { http://doi.org/10.22146/jmh.28664 } \\ \text { Publisher } & : \text { Faculty of Law Universitas Gadjah Mada } \\ \text { URL } & : \text { jurnal.ugm.ac.id/jmh } \\ \text { E Issn } & : 2443-0994 \\ \text { P Issn } & : 0852-100 \mathrm{x}\end{array}$




\title{
LEGAL POLITICS OF WATER RESOURCES MANAGEMENT IN INDONESIA: ENVIRONMENTAL PERSPECTIVE
}

\author{
Nadia Astriani* \\ Environmental Law, Faculty of Law, Universitas Padjadjaran, Bandung \\ Jl. Dipati Ukur No.35, Bandung, West Java 40132
}

\begin{abstract}
Water is a vital component for all living things. It needs the rules, both in the form of legislation and traditions norms of society, so that the benefits can be felt by all parties. The aims of this article is to understand about the legal politics of water resources management in Indonesia from environmental law perspective. The research method used in this research is normative juridical research method. The results explain that regarding water resources management, Constitutions places the State as the ruler of water resources. In practice, the state divides its management authority to private parties, thus causing water privatization. This condition is contrary with environmental law point of view.
\end{abstract}

Keywords: environmental law, legal politics, water resource, .

\section{Intisari}

Air merupakan komponen vital dalam kehidupan seluruh mahluk hidup. Karena itu dibutuhkan aturan, baik berupa perundang-undangan maupun norma dan tradisi masyarakat, agar manfaatnya dapat dirasakan semua pihak. Tujuan penelitian ini adalah memahami mengenai politik hukum pengelolaan sumber daya air di Indonesia dari perspektif hukum lingkungan. Hasil penelitian menjelaskan bahwa dalam pengelolaan sumber daya air, konstitusi menempatkan Negara sebagai penguasa sumber daya air yang memanfaatkannya untuk sebesar-besarnya kemakmuran rakyat. Praktiknya, negara membagi kewenangan pengelolaannya kepada pihak swasta, sehingga menyebabkan privatisasi air, yang bertentangan dengan cara pandang hukum lingkungan.

Kata Kunci: hukum lingkungan, politik hukum, sumber daya air.

\section{Pokok Muatan}

A. Introduction 187

B. Discussions 189

C. Conclusion 198

Correspondence address: nadia.astriani@unpad.ac.id. 


\section{A. Introduction}

The importance of water for human life as well as oxygen $\left(\mathrm{O}^{2}\right) .{ }^{1}$ The presence of water is often used as a sign of life on a planet. The small amount of water in a region can also be used as an indicator of the small amount of biodiversity in a region. ${ }^{2}$ Naturally from rainfall, the availability of water in Indonesia is sufficient. Indonesia is one of the five countries with the largest water availability in the world. Water availability in Indonesia reaches $15,000 \mathrm{~m}^{3} /$ capita/year, still above the world average of only $8,000 \mathrm{~m}^{3} / \mathrm{capita} /$ year. However, the potential of water availability in Indonesia is not linear with the population spread. For example, Java Island covering $7 \%$ of the total land area of Indonesia only has $4.5 \%$ of the total national freshwater potential. However, the island is inhabited by about $65 \%$ of the total population of Indonesia. This condition illustrates that the potential of water scarcity in Java is very large. ${ }^{3}$

Ercin and Hoekstra mention the main factors that will affect the availability of global water resources are: population growth, economic growth, changes in production patterns and trade, increased competition over water due to increased demand for household, industrial and agricultural purposes and the manner in which various the community sector will respond to increasing water scarcity and pollution. ${ }^{4}$ An increase in population and economic output can lead to a scarcity of natural resources, which in turn spurred the conflict. This has already happened in Indonesia. Water scarcity causes a variety of horizontal conflicts. An example is the seizure of water for agricultural needs. In addition, the privatization of water also causes the closed access of clean water for the economically weak. In this stage of scarcity, the principle of fairness in water management becomes very important.

The position of water as a human right and the current condition of water availability cause the management of water resources to be regulated explicitly. The legal political direction towards the utilization and/or utilization of water resources in Indonesia is obliged to be constructed as part of the state responsibility to fulfill the livelihood of Indonesian citizens of water needs in their various activities. In the context of the state, the existence of water is one aspect that becomes the state control as the constitutional mandate. ${ }^{5}$ Since the cancellation of Law No. 7 of 2004 on Water Resources by the Constitutional Court on February 18, 2015 through Decision No. 85/PUU-XI/2013. Indonesia does not yet have specific legislation on Water Resources. The basis for the cancellation of such Law based on the Constitutional Court is because the government in terms of water resources management does not hold on. This restriction is to ensure the right of state control over water resources and also to eliminate privatization. The six limitations are composed of: ${ }^{6}$

1. Any exploitation of water shall not interfere with, exclude, let alone exclude the people's right to water;

2. The State shall fulfill the people's right to water. As considered above, access to water is one of its own right: "protection, promotion, enforcement, and fulfillment of human rights are the responsibility of the state, especially the government";

3. Must remember the preservation of the environment;

4. As an important production branch and which controls the livelihood of the people that must be controlled by the state, the supervision and control by the state on water is absolute;

5. As a continuation of the right to control by the state and because water is a matter of great control over the livelihood of the public, the main priority given by the exploitation of water is a State-Owned Enterprise or

\footnotetext{
Suteki, 2010, Rekonstruksi Politik Hukum Hak Atas Air Pro-Rakyat, Surya Pena Gemilang, Semarang, p. 3.

Gunawan Jusuf, 2015, Blue Gold: Emas Biru Sumber Nyawa Kehidupan, Berita Nusantara, Jakarta, p. 16.

Ibid., p. 26.

Hary Jocom et al, “Air dan Konflik: Studi Kasus Kabupaten Timor Tengah Selatan”, Jurnal Ilmu Lingkungan, Vol. 14, No. 1, 2016. pp. 51-61

Ria Casmi Arrsa, "Telaah Socio Legal Terhadap Terwujudnya kekuatan Hak Atas Sumber Daya Air", Jurnal Rechtsvinding, Vol. 4, No. 2, 2015.

Constitutional Decree No. 85/PUU-XI/2013 concerning Reviewing Law No. 7 of 2004 on Water Resources.
} 
Regional-Owned Enterprise;

6. If after all of the above restrictions have been fulfilled and there is still water availability, the government is still allowed to grant licenses to private businesses as long as the government is still conducting water on certain conditions and strict. ${ }^{?}$

The failure of water resources management in Indonesia has been seen in the problems that arise in the field. Briefly the problem of water resources management in Indonesia is divided into 3 (three), namely:

1. Drought, ${ }^{8}$ drought is the lack of water for human life and other living things in an area that is usually not water short. According to the Ministry of Public Works, drought disaster can be viewed from the cause, that is natural causes and causes of human activities:

a. A natural drought consists of meteorological droughts associated with below normal rainfall levels in a season, hydrological drought associated with a shortage of surface water and ground water supply, agricultural drought associated with soil moisture deficiency that is unable to meet the needs of a particular crop at a given time period large areas, and hydrocotopographic drought associated with changes in river water levels between the rainy season, the dry season and the topography of the land.

b. Human-induced droughts are caused more by human disobedience to the prevailing rules of procedure, such as greater water demand than planned supply due to disobedience of the user to cropping patterns or water use patterns and water catchment damage due to human actions.

2. Flood, ${ }^{9}$ theoretically the flood is the sinking of land by water. Flooding is generally caused by river water that overflows into the surrounding environment due to rain falling in large quantities and lasting continuously. Rain that falls in high intensity can also cause flooding. In addition to natural factors, floods are also indirectly caused by several things, namely:

a. Deforestation without being followed by replanting;

b. Siltation of the River;

c. Disposal of garbage indiscriminately, either to the river stream or urban sewerage;

d. Unreliable drainage;

e. Making embankments that are not good for sea water, rivers or lakes so that overflow and inundate the land.

3. Environmental Pollution through Water Bodies, ${ }^{10}$ The development of industry and the population in addition to the effect on the quality of the increase in water demand, also gives a negative effect on the quality of water bodies in the form of garbage and toxic hazardous materials. The flow of waste into the water body is thought to be caused by several things, namely:
a. Low public knowledge about waste and waste Management;
b. The absence of a clean living culture from the Community; 
c. Less functioning of existing waste management so that people do not know how the waste should be managed properly and properly.

While toxic hazardous materials come from industrial waste. The introduction of toxic hazardous materials directly into the water body without being processed first is an offense. Weak law enforcement leads to the disobedience of industry players in managing waste.

The problems as aformentioned show that the management of water resources in Indonesia has not been implemented in accordance with environmental principles. It is therefore of interest to further investigate whether the legal politics of water resources management in Indonesia are consistent with the principles of fairness and sustainability in environmental law.

\section{B. Discussion}

Political Law in the context of Indonesia is a basic policy of state administration in the field of law that will, is and has passed, derived from the values prevailing in society to achieve the intended state goals. ${ }^{11}$ Political Law contains two inseparable sides, namely: ${ }^{12}$

1. as the direction of law-making or policy of state institutions in the making of law;

2. a tool for assessing and critiquing whether a law is made in accordance with the policy framework to achieve the state's objectives.

Legal political restrictions to achieve state goals with a national legal system according to Mahfud MD at least include the following matters: ${ }^{13}$

1. The objectives of the desired Indonesian state or society as the political orientation of the law, including the exploration of the basic values of the purpose of the state as the political guide of the Law;
2. The national legal system necessary to achieve that goal and the factors that influence it;

3. Planning and frame of mind in the formulation of legal policy;

4. The contents of national law and the factors that influence it;

5. Law enforcement with prolegnas and judicial review, legislative review and so on.

Because legal politics is defined as an attempt to make law a process of achieving goals and goals, the politics of national law must stand on the following basic framework: ${ }^{14}$

1. The politics of national law should always lead to the ideals of a nation that is a just and prosperous society based on Pancasila;

2. National legal policy should be aimed at achieving the objectives of the state, as follows:

a. Protect the whole nation and the entire blood of Indonesia;

b. Promote public welfare;

c. Enrich the life of a nation; and

d. Carry out world order based on independence, eternal peace and social justice.

3. Politics The national law must be guided by the values of Pancasila as the basis of the state, as follows:

a. Moral and religious based;

b. Respect and protect human rights without discrimination;

c. Unite all elements of the nation with all its primordial ties;

d. Laying power under the people's power; and

e. Building social justice.

4. If it is related to the ideals of the Indonesian state, then the politics of national law must be guided by necessity as follows:

a. Protect all elements of the nation for the integration or integrity of the nation that includes ideology and territory;

b. Realizing social justice in the economy and society;

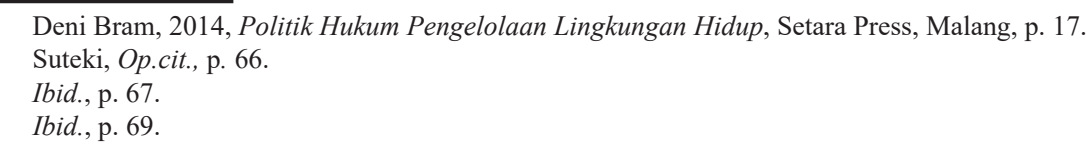


c. Realizing democracy (popular sovereignty) and nomocracy (rule of law); and

d. Creating tolerance of religious life based on civilization and humanity.

As the legal development paradigm, according to Mahfud MD, Pancasila has at least four guiding rules that should be used as guidance in the formation and enforcement of law in Indonesia, as follows: ${ }^{15}$

1. The law must protect the whole nation and guarantee the integrity of the nation and therefore there should be no law that instill seed disintegration;

2. The law should ensure social justice by providing special protection for the weaker classes in order not to be exploited in free competition against strong groups;

3. Law must be built democratically as well as build democracy in line with nomocracy (state law);

4. The law should not be discriminatory on the basis of any primordial ties and should encourage the creation of religious tolerance based on humanity and civility.

In the economic field there are 4 (four) functions of the state, namely as the guarantor (provider) of people's welfare, regulators, entrepreneurs or run certain sectors through stateowned and umpire to formulate fair standards on the state corporation. ${ }^{16}$ The function of the state as stated by W. Friedman, shows that in fact the state welfare state may intervene in the economic field, while the night watch country insists that the government should not interfere in the economic field. This shows that basically, the guardians of the night state are democratic understanders who prefer liberty rather than equality. ${ }^{17}$

The understanding of the welfare state has been rooted in the culture of Indonesian society long before Indonesia became independent. Inscription
Kedukan Bukit in Palembanga year 683 AD during the dynasty syailendra, shows that the people at that time was determined to establish a victorious, prosperous and prosperous Sriwijaya state. Wirjono Prodjonikno describes the greeting of Javanese poet "negara panjang hapunjung, hapasir wukir loh jinawi, gemah ripah karto raharjo" that often puppeteers when puppet plays are their pandanggan about welfare state. ${ }^{18}$ Bung Karno in the explanation of the Precepts of Social Justice on June 1, 1945, emphasized that democracy in Indonesia must be a deliberative life-giving, politieke economische democratie capable of bringing social welfare. So the principle of sociale rechtvaardigheid (social justice), not only talk of political equality but also equation in economic field. After going through discussions at meetings BPUPKI and PPKI finally agreed that the understanding of welfare as the understanding of the state of Indonesia contains the understanding of political democracy and economic democracy. This agreement was then articulated in Article 33 of the 1945 Constitution of RI. In addition to the welfare state, Indonesia is also a legal state. This causes the law to be used as a means to organize and organize and ensure the welfare of its people. Therefore it is necessary to develop a national legal system that will be used to support the fulfillment of such responsibilities. ${ }^{19}$

Limitations of Interest concerning the livelihood of the people can be seen from the various interests that lead to the public interest. While the public interest refers to the public interest. The life of the people themselves can be seen from its elements, namely: ${ }^{20}$

1. The existence of public interest;

2. There is a vital need for people to be processed more efficiently by taking into account the continuity of the provision of needs;

3. The existence of security for the people

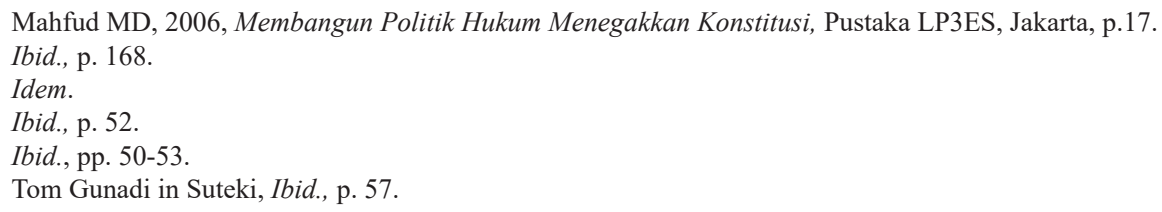


as consumers or users;

4. To play an important role for the state, both from the strategic aspect (concerning the security and responsibility of the state) and financially (bring in the revenue for the state treasury);

5. The existence of the basic spirit of the economy as a joint business based on kinship, to eliminate extreme inequality in terms of income and power;

6. It is a source for the prosperity and prosperity of the people;

7. The existence of a balance principle in the management of economic resources and utilization for the people.

This criterion can be used as a benchmark whether a particular object has the character of controlling the livelihood of the people or vice versa. Furthermore, it can be determined whether a branch of production or economy needs to be controlled by the state or not. ${ }^{21}$

Water resources are common resources resources that must be jointly managed. Therefore, rules are needed, whether in the form of state legislation to the norms and traditions of the people. In the Indonesian Constitution Article 33 paragraph (3), the State controls water, the notion of the right to control the state in relation to water is in the context of the state as the personification of all the people, so the context of mastering is not "owning". ${ }^{22}$ Rather it becomes the basis for the country to: ${ }^{23}$

1. Organize and organize the use, use, inventory and maintenance of water;

2. Determine and regulate the legal relationship between people with water;

3. Determine and regulate legal relationships between persons and legal actions concerning water.
The law of water resources in Indonesia started from the time of the kingdom. New formal rules existed during the colonial period of 1936. The next was replaced by Law No. 11 of 1974 on Irrigation and Law No. 7 of 2004 on Water Resources. ${ }^{24}$ The types of legal arrangements on water resources in Indonesia can be divided into three types, namely: based on customary law, based on the laws of the Dutch East Indies based on the Indische Staatsregeling (IS) and post-independence legislation based on the 1945 Constitution amendment. These three kinds of laws have properties and patterns that are different from each other. The nature and style of the rule of law based on the provisions of the Dutch East Indies legislation based on IS is individualistic and liberal. This characteristic is clearly seen in the institution of land ownership (eigendom) according to Article 571 Burgerlijk Wetboek (BW), which is characteristic of liberal and individualistic legal systems. Whereas the 1945 Constitution, insofar as it concerns land and water as stipulated in the Basic Agrarian Law/BAL, adopted "social functioning property rights", not the absolute property rights as written in "eigendom right" according to BW. ${ }^{25}$ In addition each rule has a basis for the preparation of rules in accordance with the prevailing paradigm of his time. ${ }^{26}$

In the Dutch colonial period, the authority associated with water resources was regulated in the Algemeen Water Reglement (AWR) in 1936. At this time the development of water resources is more defined as the development of technical irrigation to support sugarcane plantations built since the mid-19th century. The water resources management principle is monopolistic. Water Resources is owned by the government and is intended to support the business interests of the Dutch colonial

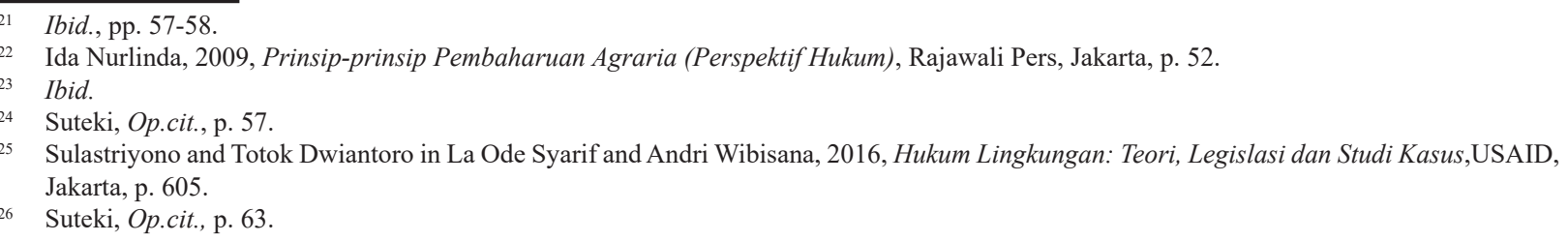


government. ${ }^{27}$ In the period after the independence of Indonesia, in the old order the problem of water is still regulated by AR 1936. New in the new order regime of water resources regulated in Law No. 11 Year 1974 on Water Resource. Water resources management system based on Law No. 11 of 1974 on Water Resource, if related to environmental management and pollution control, is not yet an integrated and comprehensive management system. ${ }^{28}$

The difference of Law No.11 of 1974 on Water Resource with AWR 1936 is: First, Law No. 11 of 1974 provides wider scope of authority to the state in the development and management of water resources and is not limited to irrigation alone, but also includes the development of ground water up to flood control, water resources management for various purposes. Second, unlike AWR 1936 which applies only in Java and Madura, Law No.11 of 1974 applies to all of Indonesia. Indonesia's development based on modernization theory is measured by rapid economic growth rate. In accordance with the paradigm used, then in Law No.11 of 1974 water resources controlled by the state and used as much as possible for the welfare of the people in accordance with Article 33 of the 1945 Constitution and the concept of implementation is done in a centralistic manner. The state acts as a regulator and provider because it has some political interests.

The government uses monocentric principles and acts as a single authority. In the late 1980s the theory of modernization underlying the New Order development paradigm began to change with the socio-cultural development theory and began to emphasize participatory human development. In the case of irrigation, government policy is to hand over irrigation management to petan, besides through Government Regulation No. 14 of 1987 on the Delivery of Part of Government Affairs in the Field of Public Works to the Region, the implementation of Operation and Maintenance Irrigation submitted to the Provincial Government while the community development on the district government. This shows that the government has implemented a functional decentralization policy in the regions. ${ }^{29}$

The economic theory of neoliberalism that developed in the late 1980s affected the paradigm of water resources management, as seen in the 1992 Dublin Convention. The convention produced four principles: ${ }^{30}$

1. Water is a resource that is vulnerable and important for the sustainability of human survival;

2. Requires broad community participation;

3. Requires a broader role for women in their management because women in their working functions are very broadly related to water;

4. Water is an economic good.

Entering the turn of the $21^{\text {st }}$ century, Indonesia experienced a monetary crisis. To overcome this crisis, Indonesia received funding from IMF and donor agencies such as the World Bank and Asian Development Bank (ADB). One of the requirements requested by donors is that Indonesia must reform the management of water resources. In the loan scheme, the Water Resources Sector Adjustman Loan (WATSAL) program was launched. The government embarked on a reform of water resources management policy with reform of irrigation management policy through Presidential Instruction no. 3 of 1999 followed by Government Regulation No. 77 of 2001 on Irrigation and the issuance of Law no. 7 of 2004 on Water Resources. ${ }^{31}$

Management of water resources in Law No. 7 of 2004 on Water Resources philosophically is essentially the same as the philosophy of Global Water Partnership (GWP), namely sustainability. Based on the philosophy, the principles/principles

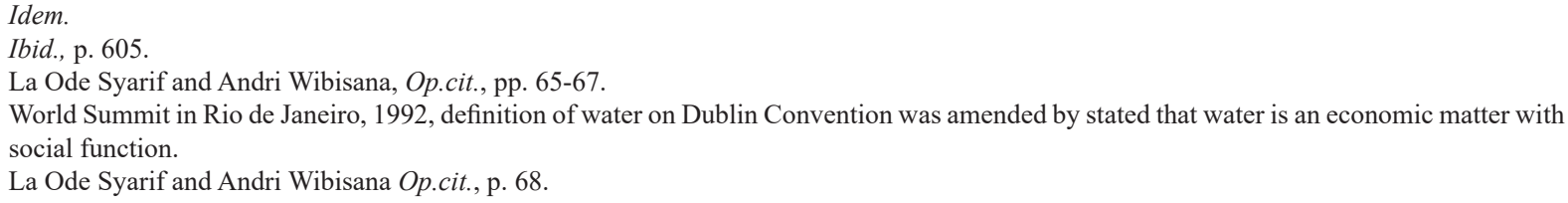


of water resources management in Law No. 7 of 2004 consists of the principles of sustainability, balance, general benefit, integrity and harmony, justice, independence and transparency and accountability. ${ }^{32}$ The substance of water resources management regulated by Law No. 7 of 2004, among others, concerning the expanded water coverage, as understood in Law No. 11 Year 1974 on Watering, plus sea water on land. In addition, the substance of the regulation by Law No. 7 of 2004 is more comprehensive covering the domain of management (conservation of water resources, utilization of water resources, controlling and handling the destructive power of water) and its management process. UU no. 7 of 2004 also raises the rights and roles of the community in the process of water resources management. The issue is regulated in Article 11 par. (3), Article 41 par. (3) and par. (4), Article 62 par. (5), Article 75 par. (2) and par. (3), Article 82, and Article 84. Water in Law No. 7 of 2004 which briefly states water as a basic necessity, which is a right for everyone and guaranteed by the state. ${ }^{33}$

Some of the things that are recorded in Law No. 7 Year 2004 are:

1. The existence of the article which states that the water resources are controlled by the state and used for the greatest prosperity of the people shows that the state persnaturally remains socialist in protecting the rights and interests of the people to obtain the basic necessities of life. This socialistic characteristic is also shown by placing social and environmental functions more important than economic functions that tend to favor the owners of capital.

2. Communities, including the private sector, are given the widest role to engage in water resources management efforts. The involvement of the private sector in all areas of water resources management demonstrates that this law also continues to accommodate economic and market functions.

3. Although socialistic, the government as the party that exercises the authority to control the water resources still performs the water resources management function that is polisentrisitas.

4. To further strengthen the function of justice between users, the right to use water is divided into the right to use and the right to use. However, if there are no clear implementation rules, such justice functions will be biased.

5. Although the public and the private sector are generally given a substantial portion of the role, irrigation management is still dominated by the government.

Law No. 7 of 2004 is then revoked by the Constitutional Court because it violates Article 33 of the 1945 Constitution and open up a wide space for water privatization. According to the Constitutional Court, the regulation of water resources should be based on the principle of state control over water resources for the welfare of the people. The Constitutional Court means that it is controlled by the State including the authority of the State to:

1. Make a policy (beleid),

2. Conduct maintenance (bestuursdaad) with the authority to issue and revoke the licensing facility (vergunning), license (licentie), and concession (concessie).

3. Perform regulatory functions (reglendaad) through legislation authority by the Parliament together with the government, and regulation by the Government (executive).

4. Conducting management (behersdaad) is done through share-holding 
mechanism and/or through direct involvement in the management of State-Owned Enterprises or StateOwned Legal Entities

5. Conducting supervision (toezichthoudensdaad) in order that the exercise of state control over the production branch which is important and/or which controls the livelihood of the people referred to is really done for the greatest prosperity of the people.

In the case of Water Concession, the Constitutional Court has already set six water limitation principles, namely: (1) Any exploitation of water shall not interfere with, override, let alone exclude the people's right to water; (2) The State shall fulfill the people's right to water. As considered above, access to water is one of its own rights, "Protection, promotion, enforcement and fulfillment of human rights are the responsibility of the state, especially the government"; (3) Must remember the preservation of the environment; (4) As an important production branch and which controls the livelihood of the people that must be controlled by the state, the supervision and control by the state on water is absolute; (5) As a continuation of the right to control by the state and because water is a matter of great control over the livelihood of the public, the main priority given by the exploitation of water is a State-Owned Enterprise or Regional-Owned Enterprise; (6) If after all the above restrictions have been fulfilled and there is still water availability, the government is still allowed to grant permission to private business as long as the government is still conducting water exploitation under certain conditions and strict. ${ }^{34}$

Although Law No. 11 of 1974 was reenacted, but the arrangements contained in Law No.11 of 1974 are not able to accommodate the existing needs. So in essence Indonesia does not currently have a law that specifically regulates the Water Resources in accordance with current and future needs.

To avoid a legal vacuum, after the cancellation of Law No.7 of 2004, the government made a number of Ministerial Regulations to regulate water resources. Consists of, among others:

1. Ministerial Regulation of PUPR Number $04 / \mathrm{PRT} / \mathrm{M} / 2015$ on Criteria and Determination of River Region;

2. Regulation of the Minister of PUPR Number 06/PRT/M/2015 on Exploitation and Maintenance of Water umber and Irrigation Building;

3. Regulation of the Minister of PUPR Number 07/PRT/M/2015 on Coastal Protection;

4. Ministerial Regulation of PUPR Number 08/PRT/M/2015 on Stipulation of Line of Irrigation Network;

5. Regulation of the Minister of PUPR Number 09/PRT/M/2015 on the Use of Water Resources;

6. Regulation of the Minister of PUPR Number 023/PRT/M/2015 on Management of Irrigation Assets;

7. Regulation of the Minister of Public Works No. 30/PRT/M/2015 on the Development and Management of Irrigation Systems;

8. Regulation of the Minister of PUPR Number 27/PRT/M/2015 on Dams;

9. Ministerial Regulation of PUPR Number 29/PRT/M/2015 on Swamp;

10. Regulation of the Minister of PUPR Number 13/PRT/M/2015 on Emergency Disaster Management;

11. Regulation of the Minister of PUPR Number 14/PRT/M/2015 on Criteria and Stipulation of Regional Status of Irrigation;

12. Regulation of the Minister of PUPR Number $26 / \mathrm{PRT} / \mathrm{M} / 2015$ on the 
Transfers of River Flows and/or households, water security for economic activities, Utilization of River Sections; water resistance for urban needs, water resistance

13. Regulation of the Minister of PUPR for natural carrying capacity/ecosystem, and water Number $1 / \mathrm{PRT} / \mathrm{M} / 2015$ on the resistance for water damage. Household water Irrigation Commission. security includes community/household access to

These Ministerial Regulations are made to provide legal certainty for the utilization of water resources. As can be seen in the arrangement, the focus of water resource utilization in various ministerial regulations is the utilization to support agriculture through irrigation. This is in accordance with the government's policy on water resources management as stated in the National Long Term Plan and Medium Term Plan, where the ultimate goal of water resources policy is water security, which is divided into water resilience for PDAM (Water Company Regional Water Supply) and adequate sanitation services. Water security for economic activity, generally measured by the adequacy of water supply for agriculture, industry, and for energy related activities. Water security for urban needs includes urban water supply, water for pollution treatment, and water for flushing/cleaning of drainage facilities. As for the carrying capacity of natural / ecosystem, water resistance is measured from the adequacy of water for the sustainability of ecosystem function. ${ }^{35}$ 
Picture. 1.

Water Resources Management Policy of Indonesia

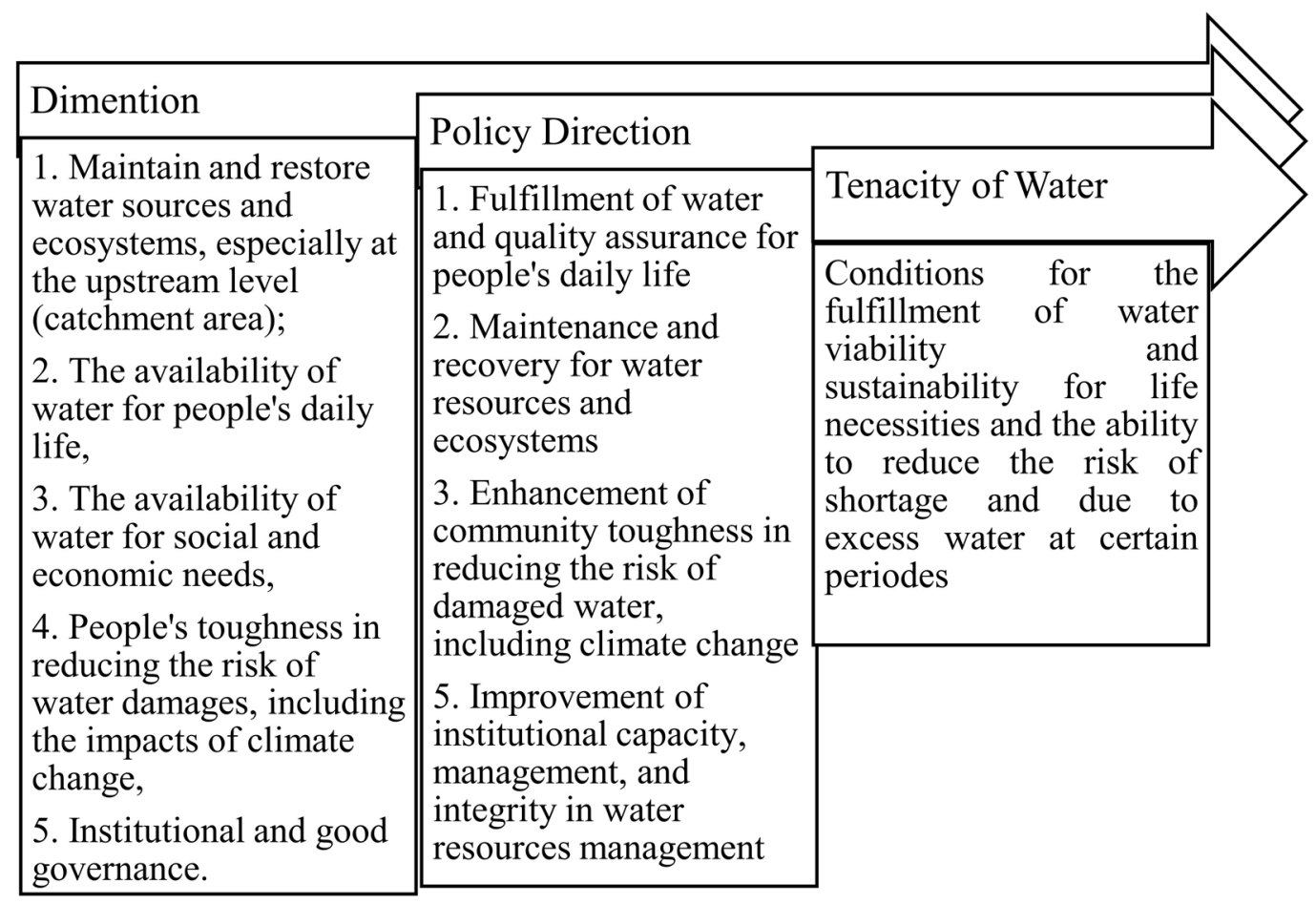

Source: compiled by Author, 2017.

To succeed the water resources management policy that has been determined, 5 (five) factors to be considered are:

a. Cooperation in coordination between sectors and between regions, the water does not recognize borders so that good cooperation between local governments in water management is required. In addition, water is closely linked to other sectors that also require water resources, so inter-sectoral coordination becomes important.

b. Sources of funding, management of water resources from upstream to downstream require substantial funding. So that water resources management programs need to be budgeted properly.

c. Stability and political commitment, Water is a human right that must be guaranteed by the government. The fulfillment of this right should be a political commitment that can only be achieved through political stability.

d. Good governance, good governance is required to manage good water resources, because good governance encourages community involvement in water resources management

e. Strict regulation, the need for water resources is so great that it is vulnerable to conflicts. Therefore strict regulation is necessary to prevent conflicts and ensure that these water resources are equitably and equitably met.

Viewed from the perspective of Environmental Law, water management in Indonesia since the Dutch colonial era up to Law No. 7 of 2004 is still oriented to the benefits (Used Oriented). Water is seen as a resource that is utilized as much as possible for human needs/people. This is certainly contrary to the view of Environmental Law that sees water 
as part of the environment, so its arrangement is not only for human needs but for the needs of the environment itself.

The Principles of Justice and Sustainability are two very important environmental law principles related to the utilization of natural resources. The Principle of Justice speaks of how humans should behave in each other in relation to the universe and how social systems must be organized to positively impact the environment. ${ }^{36}$ The principle of Justice emphasizes equal access for all members of the community to utilize natural resources and to be involved in decision-making related to natural resource management. Included in it is providing equal opportunities for future generations to utilize these natural resources, this is referred to as intergenerational justice.

The Principle of Sustainability is a principle that supports intergenerational justice. This principle comes in line with the fact that limited economic resources, social, cultural and environmental aspects are long-term dimensioned aspects and that development takes place in an intricate ecosystem space. This principle emphasizes on the choice of alternative development of more resource-efficient and able to synchronize aspects of conservation with the wise use aspect. ${ }^{37}$

In relation to water management based on Ecological Justice, 9 (nine) water democracy principles declared by Vandana Shiva should be the basis for the regulation of water resources. The nine principles are: ${ }^{38}$

\section{Water is nature's gift}

We receive water freely from nature. We owe it to nature to use this gift in accordance with our sustenance needs, to keep it clean and in adequate quantity. Diversions that create arid or waterlogged regions violate the principles of ecological democracy.

2. Water is essential to life
Water is the source of life for all species. All species and ecosystems have a right to their share of water on the planet.

3. Life is interconnected through water

Water connects all beings and all parts of the planet through the water cycle. We all have a duty to ensure that our actions do not cause harm to other species and other people.

4. Water must be free for sustenance needs

Since nature gives water to us free of cost, buying and selling it for profit violates our inherent right to nature's gift and denies the poor of their human rights.

5. Water is limited and exhaustible if used nonsustainably. Nonsustainable use includes extracting more water from ecosystems than nature can recharge (ecological nonsustainability) and consuming more than one's legitimate share, given the rights of others to a fair share (social nonsustainability).

6. Water must be conserved

Everyone has a duty to conserve water and use water sustainably, within ecological and just limits.

7. Water is a commons

Water is not a human invention. It cannot be bound and has no boundaries. It is by nature a commons. It cannot be owned as private property and sold as a commodity.

8. No one holds a right to destroy

No one has a right to overuse, abuse, waste, or pollute water systems. Tradable-pollution permits violate the principle of sustainable and just use.

9. Water cannot be substituted

Water is intrinsically different from

\footnotetext{
A. Sonny Keraf, 2002, Etika Lingkungan, Kompas, Jakarta, p. 154.

Ibid., p. 180.

Vandana Shiva, 2002, Water Wars, South End Press, New York, p. 34.
} 
other resources and products. It cannot be treated as a commodity.

Vandana Shiva's view is influenced by the Deep Ecology theory pioneered by Arne Naess. Deep Ecology Theory based on ecosophy, a wisdom that encourages a wise lifestyle and care for nature as a household is derived from the understanding and wisdom that everything in the universe has value on its own drinya and this value far exceeds the value possessed by and for humans. So in this philosophy, not only humans have values and interests to be respected, but also the entire contents of this universe. ${ }^{39}$

Based on the above principles, in addition to the utilization of conservation becomes an important thing to be regulated in the management of water resources. Because conservation will ensure the availability of water resources and ensure the utilization of water resources by future generations. This is in line with the results of research on the management of water resources which shows that the problem of water resources management in Indonesia is related to 3 (three) things namely Availability, Utilization and Distribution.

The policy of national water resources leads to three things, namely the conservation of water resources, the utilization of water resources and the control of water damages. This is reflected in the articles of Law No. 7 of 2004, but in practice the conservation programs of water resources have not received full attention when compared to programs related to the utilization of water resources. Re-enactment of Law No. 11 of 1974, increasingly marginalize the water conservation programs because the focus of Law No. 11 of 1974 is the utilization of water resources, especially for agriculture. Therefore, new laws regarding water resources based on justice and sustainability principles should be immediately made. Because through these two principles the community's need for water resources can be met fairly and equitably.

\section{Conclusion}

Theresults ofthe analysis show that Indonesian air governance law to date has placed the country as the ruler of natural resources, including air. In its usefulness, these natural resources are used for the prosperity of the people. It is in a variety of formal rules that exist in Indonesia. In the Dutch colonial period, the regulation of water resources was aimed at supporting the sugarcane plantations on which the economy was based. Entering the New Order, the regulation of water resources is still dependent on irrigation arrangements to support agriculture in Indonesia. After the reform period, there is renewal. Reform is done by incorporating Water Conservation arrangements into law. Nevertheless the view of the air as an economic good, opens up space for the translation of air privatization in the law. The history of water resources management arrangements still has a strong anthropocentric view, just as a resource that can be utilized as much as possible for human needs. This is certainly contrary to the eccentric environmental law. Water functions are vital for all living things cause the air arrangement must be done carefully to be useful for life on earth itself. The Law of Water Resources should be based on ecocentric thinking that places the interests of the environment equal to human interests. Air characteristics that make it different from other natural resources, therefore the arrangement must be adjusted to the air characteristics. In the formation of the New Law must be based on the principle of justice and sustainability to achieve the fulfillment of the right to air in a fair and equitable. 


\section{REFERENCES}

\section{A. Books}

Bram, Deni, 2014, Politik Hukum Pengelolaan Lingkungan Hidup, Setara Press, Malang.

Jusuf, Gunawan, 2015, Blue Gold: Emas Biru Sumber Nyawa Kehidupan, Berita Nusantara, Jakarta.

Keraf, A.Sonny, 2002, Etika Lingkungan, Kompas, Jakarta.

KruHA, 2016, Kajian Hak Atas Air, Indie Book Corner, Jakarta.

Nurlinda, Ida, 2009, Prinsip-prinsip Pembaharuan Agraria (Perspektif Hukum), Rajawali Pers, Jakarta.

Suteki, 2010, Rekonstruksi Politik Hukum Hak Atas Air Pro-Rakyat, Surya Pena Gemilang, Semarang.

Syarif, La Ode and Andri Wibisana, 2016, Hukum Lingkungan: Teori, Legislasi dan Studi Kasus, USAID, Jakarta.

Shiva, Vandana, 2002, Water Wars, South End Press, New York.

\section{B. Jurnal}

Arrsa, Ria Casmi, "Telaah Socio Legal Terhadap Terwujudnya kekuatan Hak Atas Sumber Daya Air", Jurnal Rechtsvinding, Vol. 4, No.2, 2015.

Jocom, Hary, et al.,, "Air dan Konflik: Studi Kasus Kabupaten Timor Tengah Selatan", Jurnal Ilmu Lingkungan, Vol. 14, No. 1, 2016.

\section{Research Results}

Asdak, Chay, 2015, Kebijakan Nasional Konservasi Sumber Daya Air Terpadu, Final Report of Bappenas Research, Bandung.

\section{Regulations}

Law Number 11 of 1974 on Water Resources (State Gazzete of the Republic of Indonesia Year 1974, Number 65, Supplement to State
Gazzete of the Republic of Indonesia Number 3046).

Government Regulation Number 37 of 2012 on Watershed Management.

Government Regulation Number 33 of 2011 on National Policy of Water Resources Management.

\section{E. Court Decision}

Constitutional Court Decree No. 85/PUU-XI/2013 concerning Reviewing Law No. 7 of 2004 on Water Resources, 18 February 2015. 